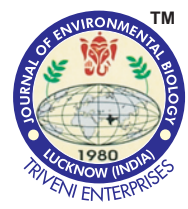

\title{
Upregulation of hepatopancreas associated lectin transcripts in Macrobrachium rosenbergii in response to Vibrio harveyi and M. rosenbergii nodavirus (MrNV)
}

\section{Authors Info}

S. Baliarsingh", M. Dash', N. Dewangan', A.S.S. Hameed ${ }^{2}$, J. Mohanty ${ }^{3}$, Y.S. Lee ${ }^{4}$ and B.B. Patnaik ${ }^{1 *}$

${ }^{1}$ School of Biotech Sciences, Trident Academy of Creative Technology,

Bhubaneswar- 751 024, India ${ }^{2}$ Aquatic Animal Health Laboratory, C. Abdul Hakeem College of Arts and Science,

Melvisharam- 632 509, India

${ }^{3}$ Fish Genetics and Biotechnology Division, ICAR-Central Institute of Freshwater Aquaculture, Bhubaneswar- 751 002, India ${ }^{4}$ Department of Life Sciences and Biotechnology, College of Natural Sciences, Soonchunhyang University, Asan, 31538, Korea

*Corresponding Author Email : drbharatbhusan4@gmail.com

\section{Edited by}

Professor Hyun Woung Shin

Reviewed by

Dr. Yeon Soo Han

Dr. Yong Hun Jo

\section{Abstract}

Aim: The giant fresh water prawn, Macrobrachium rosenbergii is widely cultured in semi-intensive farming systems for commercial production. However, the major constraint to sustainable production practices include diseases due to bacterial and viral infections. The immunity related genes contribute towards prawn health by regulating the expression of antimicrobial peptides and promoting phagocytosis. In this study, we examined the expression of $M r(T) L e c 4$ and $M r(T)$ Lec2 associated with the hepatopancreas tissue of $M$. rosenbergii adults after challenge with Vibrio harveyiand M. rosenbergii nodavirus (MrNV).

Methodology: The transcript sequences were derived from the $M$. rosenbergii transcriptome database. Gene-specific primers were designed for qRT-PCR analysis of tissue-specific expression patterns of $\operatorname{Mr}(T)$ Lec4 and $\operatorname{Mr}(T)$ Lec2 in M. rosenbergii. Subsequently, the temporal expression of transcripts were examined in the hepatopancreas tissue following challenge of the adult prawn with bacteria $V$. harveyi and $M$. rosenbergii nodavirus (MrNV). The MrNV positive inoculum used for challenge experiments were obtained from infected post-larval stages of the prawn.

Results: The relative expression of $\operatorname{Mr}(T) L e c 4$ and $\operatorname{Mr}(T) L e c 2$ in the hepatopancreas showed an increase of about 23 and 28-folds, respectively, compared with other tissues. At post- $V$. harveyi challenge, the mRNA levels of $M r(T) L e c 4$ in hepatopancreas was upregulated at $6 \mathrm{hr}$. Further, the expression pattern of $M r(T) L e c 4$ and $\operatorname{Mr}(T) L e c 2$ in hepatopancreas tissue at different time points in response to MrNV challenge was analyzed by $\mathrm{qRT}-\mathrm{PCR}$. Both the transcripts showed upregulation at $48 \mathrm{hrs}$ post-challenge confirming induction after MrNV challenge.

Interpretation: This study for the first time reports involvement of hepatopancreas-associated lectin to $V$. harveyi and MrNV challenge. A direction towards its putative role in regulation of immune response of $M$. rosenbergii is been currently investigated using RNAinterference and expression studies.

Key words: Antimicrobial challenge, Aquaculture, Carbohydrate-binding lectin domains, Macrobrachium rosenbergii, qRT-PCR

How to cite : Baliarsingh, S., M. Dash, N. Dewangan, A.S.S. Hameed, J. Mohanty, Y.S. Lee and B.B. Patnaik: Upregulation of hepatopancreas associated lectin transcripts in Macrobrachium rosenbergii in response to Vibrio harveyi and M. rosenbergii nodavirus (MrNV). J. Environ. Biol., 40, 969-976 (2019). DOI : http://doi.org/10.22438/jeb/40/5(SI)/SI-20 


\section{Introduction}

The status of giant fresh water prawn, Macrobrachium rosenbergii in the global aquaculture production is considered to be the most sustainable among the several cultivable finfish and shellfishes. There has been a moderate rise in $M$. rosenbergii production from 196,848 to 213,958 tonnes between 2004 and 2015 in many countries allowing for significant investments in the aquaculture sector (FAO, 2017). The revenue generated due to M. rosenbergii cultivation and processing in Asia alone touches $>$ US $\$ 1$ billion annually (Schwantes et al., 2009). A rapid increase in global production of $M$. rosenbergii is attributed to developed socio-economic conditions, smart culture networks, and prosperous entrepreneurial ecosystems in most aquaculturedominated countries (FAO, 2002; Ali et al., 2018). In the present context, a self-reliant economy based on sustainable freshwater prawn production seems imperative, provided viability of commercial aquaculture production continues by limiting the magnitude of disease outbreaks. Culture intensification and expansion, poor husbandry measures, transboundary movement of broodstock and post-larvae, and global climate change has brought about diseases of infectious and non-infectious aetiologies (Saurabh and Sahoo, 2008; Shailender et al., 2012; Dineshkumar et al., 2017). A thorough understanding of the host defense system through screening and characterization of genes involved in innate immune pathways is necessary towards addressing the issues to new pathogens and interactions with the host.

Lectins play dynamic role in crustacean immunity and survival by participating in cell-cell interaction, cell-signaling, protein synthesis and pathogen recognition (Denis et al., 2016; Sanchez-Salgado et al., 2017). Crustacean lectins are more dynamic as they participate in humoral defence through recognition and antibacterial activity and cellular defense through encapsulation and phagocytosis (Vazquez et al., 2009; Zhang et al., 2016). Further, diversity in ligand specificities and the ensuing effector functions can be attributed to structural differences among the lectin classes. The lectins characterized from $M$. rosenbergii include membrane-spanning L-type lectin, specifically expressed in the hepatopancreas and intestine. This participates in bacterial clearance and inhibition of white spot syndrome virus (WSSV) replication in vivo (Huang et al., 2018). Earlier reports have characterized gills and intestine-specific $\mathrm{Ca}^{2+}$-dependent lectins (C-type lectins) that can attach to lipopolysaccharide and peptidoglycan on Gram-negative and Gram-positive bacteria, respectively (Huang et al., 2016; Feng et al., 2016). A mannose-binding lectin from M. rosenbergii showed bactericidal action against most of the Gram-negative bacteria and few Gram-positive bacteria conferring resistance to microbes in the host (Arockiaraj et al., 2015). M. rosenbergii ficolins (containing fibrinogen-related domains) with greater expression in stomach were also found to possess pattern recognition function (Zhang et al., 2014). Other C-type lectins with dual carbohydrate-recognition domains (CRDs) have also been characterized from giant fresh water prawn with multiple binding specificities (Ren et al., 2012; Zhu et al., 2013). Considering the diversity of lectins in the species and defense responses to multiple pathogens, the repertoire thus far characterized seems limited. Further, with nodavirus (causative virus related to whitetail disease) isolates reported from fresh water prawn hatcheries and nursery ponds of India (Sahul Hameed et al., 2004), Thailand (Yoganandhan et al., 2006), Indonesia (Murwantoko et al., 2016), China (Zhang et al., 2006), Taiwan (Hsieh et al., 2006) and Australia (Owens et al., 2009) causing economic loss upto 100\%, a study on the defense strategy of the host with participatory role of lectins seems significant.

In the present study, two lectin transcripts [designated as $\operatorname{Mr}(T)$ Lec4 and $\operatorname{Mr}(T)$ Lec2] were studied at the level of qPCR expression analysis. The transcript sequences were retrieved from the $M$. rosenbergii hepatopancreas transcriptome database (SRX097638). Relative quantification of $M r(T) L e c 4$ and $M r(T) L e c 2$ in different tissues were confirmed. Subsequently, we studied the time-course expression profile of the transcripts in the host after challenge of the host with $V$. harveyi and M. rosenbergii nodavirus (MrNV). This study for the first time showed that hepatopancreas-expressed lectin(s) in the fresh water prawn $M$. rosenbergii responds to the Gram-negative bacteria Vibrio harveyi and to the viral pathogen MrNV. To substantiate the importance of this work, a status report of lectin family transcripts expressed in tissues of various crustacean species including $M$. rosenbergii based on immune challenge studies was prepared. Molecular characterization of $M r(T)$ Lec4 and Mt(T)Lec2 envisages to understand the key regulatory function of the transcripts during MrNV infection in the adult prawns and deduce the susceptibility mechanisms of the host during the post-larval stages.

\section{Materials and Methods}

Experimental animals and microorganisms: Healthy adult prawns, M. rosenbergii (15-17 g body weight) were obtained from local aquaculture farm (Bhubaneswar, Odisha, India) and maintained in fresh water containers under laboratory conditions. The animals were fed daily with artificial pelleted diet. Healthy post-larval stage prawns were obtained from a hatchery and screened for White-tail disease (WTD) infection by RT-PCR using published primer information (Sahul Hameed et al., 2004). These prawns were maintained in the laboratory and fed twice a day with Artemia nauplii. WTD-infected post-larvae with morphological identification of whitish muscle in the abdomen were collected from nearby hatcheries reporting this infection. These were used as a source for infectivity experiments after preparation and filtration of viral inoculum. The filtrate was confirmed by RT-PCR (Ravi et al., 2010) and stored at $-20^{\circ} \mathrm{C}$. V. harveyi strain 639 were inoculated into $10 \mathrm{ml}$ of Tryptic soy broth (TSB) $+2.5 \% \mathrm{NaCl}$ for overnight incubation at $30^{\circ} \mathrm{C}$. The optical density of the bacterial 
suspension was adjusted to 0.1 at $625 \mathrm{~nm}$ [equivalent to $10^{8}$ colony-forming units $\left(\mathrm{cfu} \mathrm{m}^{-1}\right)$ ]. For infectivity experiments, serially-diluted suspension of $10^{6} \mathrm{cfu} \mathrm{m}^{-1}$ was used.

Tissue-specific expression patterns: Tissues such as gills, muscle, hepatopancreas, stomach, and intestine were harvested from the healthy prawns $(n=3)$ and stored in RNA later stabilization solution (Thermo Fisher Scientific, MA, USA) for qRT-PCR assay. Hemolymph was drawn by directly puncturing the heart using a sterile syringe attached with a 23- gauge needle containing $1 \mathrm{ml}$ of ice-cold anticoagulant Alsever's solution (27 $\mathrm{mM}$ sodium citrate, $336 \mathrm{mM} \mathrm{NaCl}, 115 \mathrm{mM}$ glucose, $9 \mathrm{mM}$ EDTA, $\mathrm{pH}$ 4.6). The hemolymph was centrifuged at $800 \mathrm{xg}$ for 10 min at 4 ${ }^{\circ} \mathrm{C}$ to collect the hemocyte pellet. Total RNA was prepared with $100 \mathrm{mg}$ of different tissues (gill, muscle, hepatopancreas, stomach, intestine and hemocytes) using HiPurA ${ }^{\text {TM }}$ Total RNA Miniprep purification kit (Himedia Laboratories, Mumbai, India) according to manufacturer's protocol. The concentration and purity of total RNA were determined by measuring the absorbance at $260 \mathrm{~nm}$ and the ratio of optical density $\mathrm{OD}_{260 \mathrm{~nm}} / \mathrm{OD}_{280 \mathrm{~nm}}$ using a UV-Vis Spectrophotometer (Systronics India Ltd., Ahmedabad, India). The integrity of total RNA was determined using 1\% Agarose gel electrophoresis. Only RNA with purity of 1.9 to 2.1 was used for cDNA synthesis. Total RNA (4 $\mu \mathrm{g} / \mu \mathrm{l}$ ) was used as a template for cDNA synthesis using $\mathrm{Hi}-\mathrm{cDNA}$ synthesis kit (Himedia Laboratories) according to manufacturer's instructions. Quantitative changes in $M r(T)$ Lec4 and $M r(T)$ Lec2 transcripts were analyzed by qRT-PCR in an QuantStudio 3.0 real-time system (Thermo Fisher Scientific) using Hi-SYBR master-mix (HiMedia Laboratories Pvt. Ltd.). PCR was conducted in a 40 cycle amplification step comprising of denaturation at $95^{\circ} \mathrm{C}$ for $15 \mathrm{sec}$, annealing at $60^{\circ} \mathrm{C}$ for $15 \mathrm{sec}$, and extension at $72{ }^{\circ} \mathrm{C}$ for $1 \mathrm{~min}$. M. rosenbergii $\beta$-actin (Mr $\beta$-actin) was amplified as an endogenous control (qRT-PCR Fwd 5'AATCGTGCGTGACATCAAGG-3' and qRT-PCR Rev 5'TCTCGTTACCGATGGTGATGAC-3'). Gene-specific primers designed for qRT-PCR amplification of $M r(T) L e c 4$ and $M r(T) L e c 2$ were 5'-ACGTGCTTTCGAGTGCAATG-3' (Fwd)/ 5'GGTTCCCAGTAGCGAGAGATAA-3' and $5^{\prime}$ G G T T C C CA TAG C G A G A A TAA - 3'/ 5 ' GAAGGGTGCTTCACATACAACA-3', respectively.

Temporal expression patterns after infection with microorganisms: Hundred microliters of bacterial suspension were injected intramuscularly to third abdominal segment of adult healthy prawns. Uninjected adult acted as negative control because phosphate-buffered saline injected control (woundrelated effect) did not show a significant change in expression of the transcripts compared with uninjected controls. In another experiment, MrNV and extra small virus (XSV) were prepared from WTD-infected post-larvae at $10 \%$ suspension in TN buffer $(20 \mathrm{mM}$ Tris- $\mathrm{HCl}$ and $0.4 \mathrm{M} \mathrm{NaCl}, \mathrm{pH} 7.4$ ) (Ravi et al., 2010). The presence of MrNV and XSV was confirmed by RT-PCR using MrNV primers (Fwd: 5'-GCGTTATAGATGGCACAAGG-3' and Rev: 5'AGCTGTGAAACTTCCACTGG-3'; 425 bp product size) and XSV primers (Fwd: 5'- CGCGGATCCGATGAATAAGCGCATTAATAA3 ' and Rev: 5'- CCGGAATTCCGTTACTGTTCGGAGTCCCAA-3'; 546 bp product size) (Fig. 1).

MrNV and XSV inoculum (100 $\mu$ l per animal) was injected intramuscularly at the third abdominal segment of adult $M$. rosenbergii with non-injected prawns acting as negative control.

MrNV

XSV

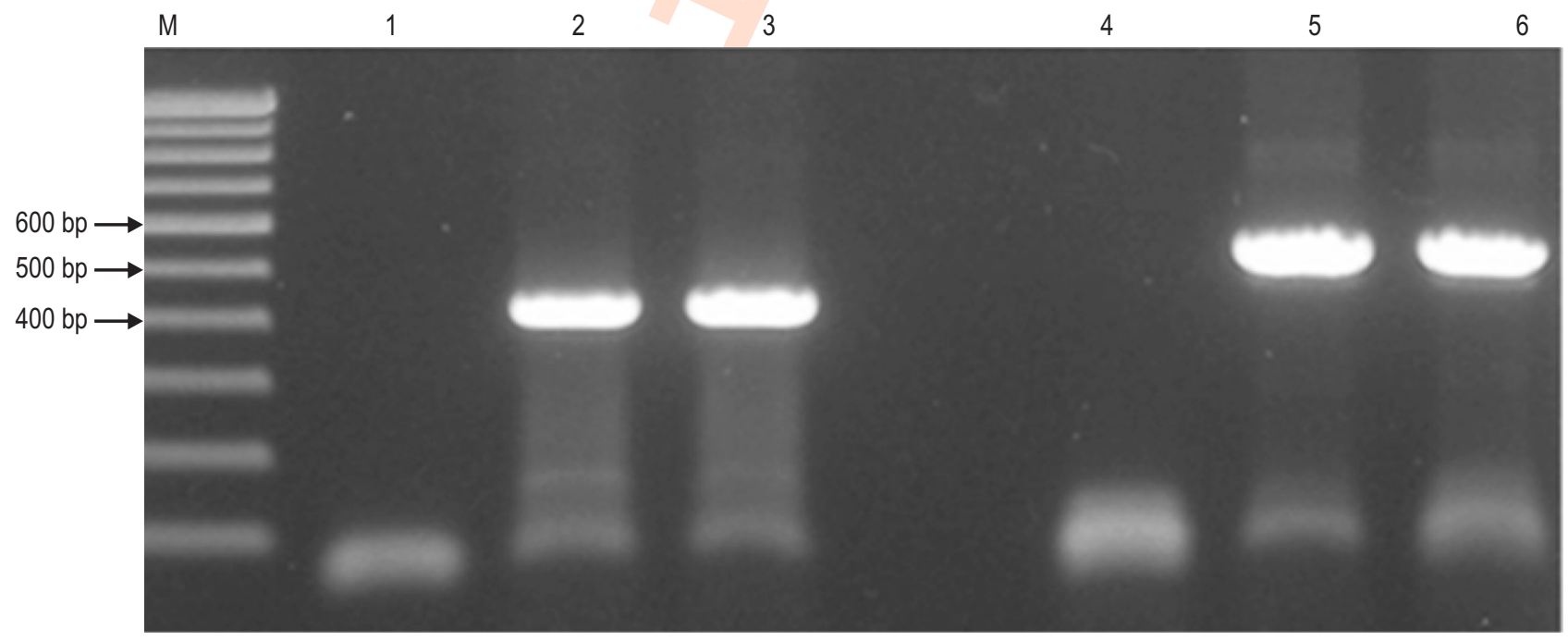

Fig. 1 : RT-PCR analysis of white-tail disease (WTD) infected post-larvae of freshwater prawn, M. rosenbergii. MrNV (M. rosenbergii nodavirus); XSV (Extra small virus)-like particle. M, 100 bp marker; Lane-1, Negative control (healthy M. rosenbergii); Lane-2, 425 bp MrNV positive control; Lane-3, 425 bp MrNV from infected post-larvae; Lane-4, Negative control (healthy M. rosenbergii); Lane-5, 546 bp XSV positive control; Lane-6, 546 bp XSV from infected post-larvae. 
Total RNA isolated from hepatopancreas tissue of adult prawns ( 3 animals per time point at 6,24 , and $48 \mathrm{~h}$ post-injection) was converted to cDNA and amplified using qPCR as detailed earlier. As a normalizing control, Mr $\beta$-actin was used. The relative expression levels were measured by the comparative $\mathrm{Ct}$ value method (Livak and Schmittgen, 2001). Results are expressed as mean \pm SD from three independent biological replications.

\section{Results and Discussion}

Based on the lectin gene repertoire available in $M$. rosenbergii hepatopancreas transcriptome database (Zhu et al., 2013), $M r(T) L e c 4$ and $M r(T) L e c 2$ transcripts were identified
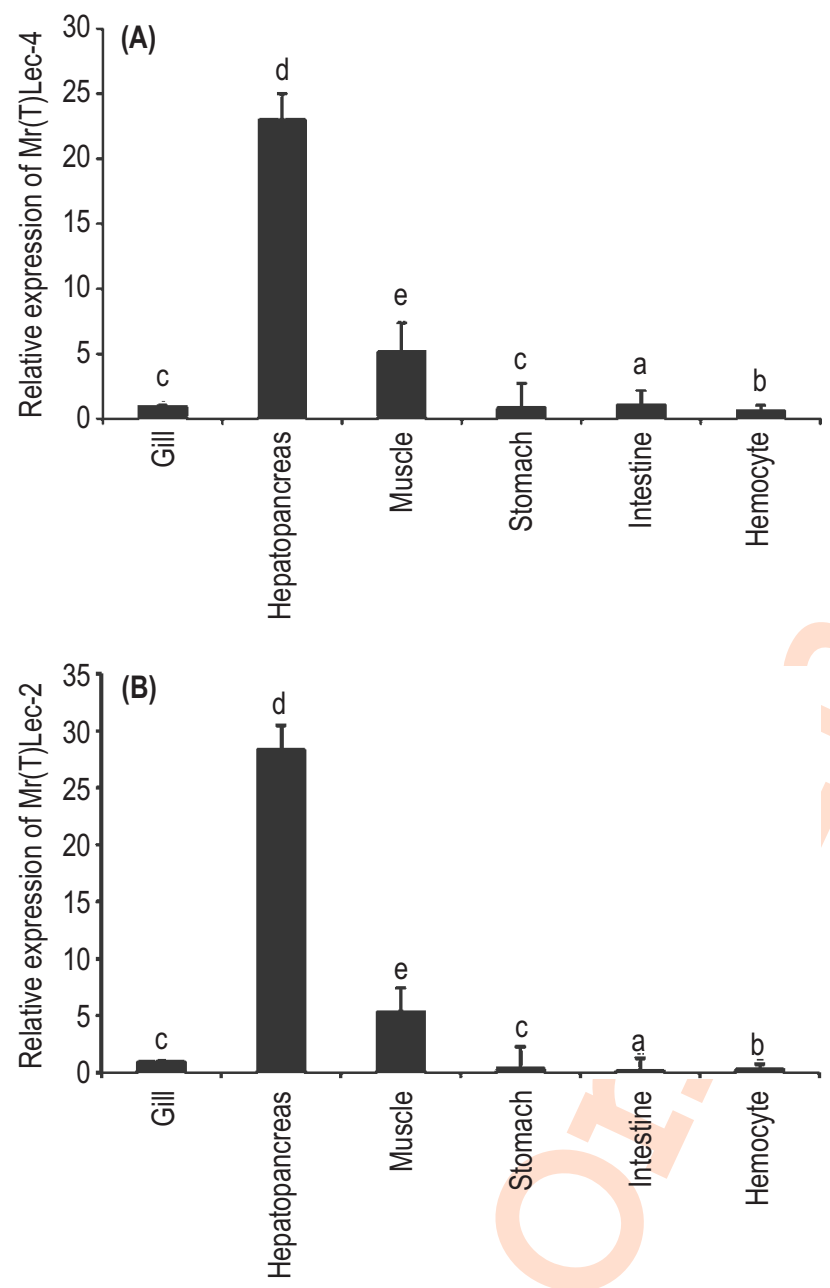

Fig. 2 : Tissue-specific expression analysis of $\operatorname{Mr}(T) L e c-4(\mathbf{A})$ and $\operatorname{Mr}(T) L e c 2$ (B). mRNA in the gill, hepatopancreas, muscle, stomach, intestine, and hemocytes of $M$. rosenbergii. Relative expression of $\operatorname{Mr}(T) L e c-4$ and $M r(T) L e c-2$ in adult tissues is shown. $\Delta \Delta C$ method was used to analyze tissue specificity. $\beta$-actin ( $M$. rosenbergii) is used as an internal control to normalize levels between samples. Vertical bars represent standard errors $(n=3) \pm$ SE. The results were statistically analyzed using one-way ANOVA and Tukey's multiple range test at $95 \%$ confidence level $(P<0.05)$. Different lowercase letters represent significant differences among groups. showing greater expression in the hepatopancreas tissue compared with other tissues (Fig. 2).

$\operatorname{Mr}(T)$ Lec4 and $M r(T)$ Lec2 transcripts were mostly localized to $M$. rosenbergii hepatopancreas tissue with relative expression of 23- and 28-folds, respectively. This was followed by a $\sim 5$-fold expression in the muscle tissue. Higher expression of lectin transcript (a L-type lectin; MrVIP36) in the hepatopancreas tissue of M. rosenbergii has been reported earlier (Huang et al., 2018). Surprisingly, the expression levels in hemocytes were significantly lower. Our results contradict the earlier finding where in Marsupenaeus japonicus C-type lectin (MjHeCL) showed hemocytes localization, and functioned by inhibiting the proliferation of hemolymph microbiota (Wang et al., 2014). In other tissues examined, $\operatorname{Mr}(T)$ Lec4 and $\operatorname{Mr}(T)$ Lec2 expression seemed considerably limited. The higher transcript abundance in hepatopancreas as compared to other tissues of $M$. rosenbergii is expected as the organ is involved in mediating strong innate immune responses in crustaceans against invading pathogens.
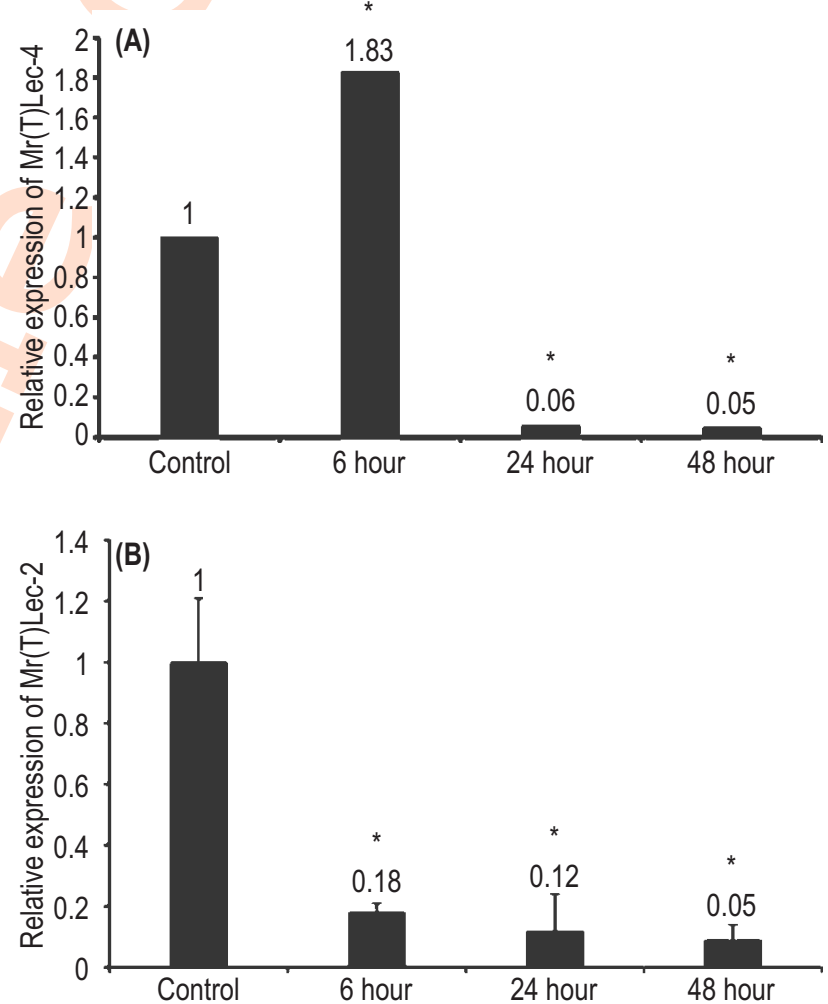

Fig. 3 : Temporal expression patterns of $M r(T) L e c-4$ (A) and $M r(T) L e c-2$ (B) in adult hepatopancreas tissue after Vibrio harveyi injection. $V$. harveyi strain 639 was injected into $M$. rosenbergii adults and samples were collected at $6 \mathrm{~h}, 24 \mathrm{~h}$, and 48 hrs post-infection. Patterns of $\operatorname{Mr}(T)$ Lec-4 were investigated, showing a significant increase $6 \mathrm{~h}$ postinjection. Uninjected adult prawns acted as the negative control. $\beta$-actin (M. rosenbergii) was used as an internal control. Results of three biological replications are represented with standard errors. ${ }^{*} P<0.05$ (SAS, ANOVA). 
Table 1 : Status survey (last five years) of lectin family transcripts expressed in tissues of $M$. rosenbergii and related genus based on immune challenge studies

\begin{tabular}{|c|c|c|c|c|c|c|}
\hline Organism & $\begin{array}{l}\text { Lectin(s) } \\
\text { family } \\
\text { transcript }\end{array}$ & Designation & Sequence features & $\begin{array}{l}\text { Immune } \\
\text { challenge }\end{array}$ & $\begin{array}{l}\text { Tissues } \\
\text { expressed }\end{array}$ & Reference \\
\hline $\begin{array}{l}\text { Macrobrachium } \\
\text { rosenbergii (Giant } \\
\text { freshwater prawn) }\end{array}$ & $\begin{array}{l}\text { Not } \\
\text { known }\end{array}$ & $\begin{array}{l}\operatorname{Mr}(T) \text {-Lec4 } \\
\operatorname{Mr}(T)-\operatorname{Lec} 2\end{array}$ & $\begin{array}{l}\operatorname{Mr}(\mathrm{T}) \text {-Lec4: } 69 \text { bp partial ORF sequence } \\
\text { and } 177 \text { bp 3'-UTR (overlap sequence) } \\
\operatorname{Mr}(\mathrm{T}) \text {-Lec2: Not reported }\end{array}$ & $\begin{array}{l}\text { M. rosenbergii } \\
\text { nodavirus (MrNV), c } \\
\text { Vibrio harveyi }\end{array}$ & $\begin{array}{l}\text { Hepatopan- } \\
\text { creas }\end{array}$ & This study \\
\hline M. rosenbergii & $\begin{array}{l}\text { L-type } \\
\text { lectin }\end{array}$ & MrVIP36 & $\begin{array}{l}972 \text { bp ORF encoding } 323 \text { aa protein, } \\
\text { L-type CRD and a TM domain, } \\
\text { Agglutinates Gram-positive and } \\
\text { Gram-negative bacteria, Facilitates } \\
\text { bacterial clearance in vivo and inhibits } \\
\text { WSSV replication in vivo }\end{array}$ & $\begin{array}{l}\text { Staphylococcus } \\
\text { aureus, Vibrio } \\
\text { parahaemolyticus, } \\
\text { White Spot Syndrom } \\
\text { Virus (WSSV) }\end{array}$ & Haemocytes & Huang et al., 2018 \\
\hline $\begin{array}{l}\text { Macrobrachium } \\
\text { nipponense } \\
\text { (Oriental river } \\
\text { prawn) }\end{array}$ & Ficolin(s) & $\begin{array}{l}\text { MnFico1 } \\
\text { MnFico2 }\end{array}$ & $\begin{array}{l}\text { Agglutinates Gram-positive and Gram- } \\
\text { negative bacteria in presence of } \mathrm{Ca}^{2+} \text {, } \\
\text { Facilitates clearance of } \\
\text { V. parahaemolyticus in vivo }\end{array}$ & $\begin{array}{l}\text { V.parahae- } \\
\text { molyticus }\end{array}$ & $\begin{array}{l}\text { MnFico1: Gills } \\
\text { MnFico2: Heart }\end{array}$ & Lietal., 2017 \\
\hline M. nipponense & $\begin{array}{l}\text { C-type } \\
\text { lectin }\end{array}$ & $\mathrm{MnCTL}$ & $\begin{array}{l}774 \text { bp ORF encoding } 257 \text { aa residues, } \\
\text { Single CRD with an EPN motif, } \\
\text { Agglutinates Gram-positive and Gram- } \\
\text { negative bacteria in presence of } \mathrm{Ca}^{2+}\end{array}$ & WSSV & Gills, Stomach & Huang et al., 2017 \\
\hline M. rosenbergii & $\begin{array}{l}\text { C-type } \\
\text { lectin }\end{array}$ & MrLec & $\begin{array}{l}1041 \text { bp ORF encoding } 346 \text { aa, } \\
18 \text { aa signal peptide and single CRD, } \\
\text { Agglutinates Gram-positive and Gram- } \\
\text { negative bacteria in presence of } \mathrm{Ca}^{2+}\end{array}$ & $\begin{array}{l}\text { V.parahaem- } \\
\text { olyticus } \\
\text { WSSV }\end{array}$ & $\begin{array}{l}\text { Gills } \\
\text { Intestine }\end{array}$ & Feng et al., 2016 \\
\hline M. rosenbergii & $\begin{array}{l}\text { C-type } \\
\text { lectin }\end{array}$ & $\mathrm{MrCTL}$ & 657 bp ORF encoding 218 aa protein & $\begin{array}{l}\text { V. parahaem- } \\
\text { olyticus WSSV }\end{array}$ & Gills, Intestine & Huang et al., 2016b \\
\hline M. rosenbergii & $\begin{array}{l}\text { C-type } \\
\text { lectin }\end{array}$ & MrLec & $\begin{array}{l}801 \text { bp ORF encoding } 266 \text { aa protein, } \\
\text { Single CRD (EPN motif), } \\
\text { Regulation of AMP expression, Agglutinates } \\
\text { Gram-positive and Gram-negative bacteria } \\
\text { in presence of } \mathrm{Ca}^{2+}\end{array}$ & $\begin{array}{l}\text { Vibrio } \\
\text { haemolyticus }\end{array}$ & Gills & Huang et al., 2016a \\
\hline M. nipponense & $\begin{array}{l}\text { C-type } \\
\text { lectin }\end{array}$ & MnCTLDcp1 & $\begin{array}{l}999 \text { bp ORF encoding } 332 \text { aa protein, } \\
\text { LDLa and single CTLD }\end{array}$ & $\begin{array}{l}\text { Aeromonas } \\
\text { hydrophila } \\
\text { S. aureus }\end{array}$ & $\begin{array}{l}\text { Heart } \\
\text { Haemocytes }\end{array}$ & Xiu etal., 2016 \\
\hline M. nipponense & $\begin{array}{l}\text { C-type } \\
\text { lectin(s) }\end{array}$ & $\begin{array}{l}\text { MnCTLDcp2 } \\
\text { MnCTLDcp3 }\end{array}$ & $\begin{array}{l}\text { MnCTLDcp2: } 972 \text { bp ORF encoding } \\
323 \text { aa protein, MnCTLDcp3: } 555 \text { bp } \\
\text { ORF encoding } 184 \text { aa protein,Single CRD } \\
\text { (in both), LDLa domain and signal } \\
\text { peptide in MnCTLDcp2 }\end{array}$ & Bacteria & Heart & Xiu etal., 2015a \\
\hline M. nipponense & $\begin{array}{l}\text { M-type } \\
\text { lectin } \\
\text { L-type } \\
\text { lectin }\end{array}$ & $\begin{array}{l}\text { MnMTL1 } \\
\text { MnLTL1 }\end{array}$ & $\begin{array}{l}\text { MnMTL1: } 1761 \text { bp ORF encoding } \\
586 \text { aa protein; type-II TM region and } \\
\text { GH family } 47 \text { domainMnLTL1: } 1744 \text { bp } \\
\text { ORF encoding } 323 \text { aa protein; one } \\
\text { CRD and type I TM domain }\end{array}$ & $\begin{array}{l}\text { A. hydrophila } \\
\text { Aeromonas veronii }\end{array}$ & All tissues & Xiu et al., 2015b \\
\hline M. rosenbergii & $\begin{array}{l}\text { Mannose- } \\
\text { binding } \\
\text { lectin(s) }\end{array}$ & $\begin{array}{l}\text { MrMBL-N20 } \\
\text { MrMBL-C16 }\end{array}$ & Notreported & Virus, Bacteria & Gills & Arockiaraj etal., 2015 \\
\hline M. rosenbergii & $\begin{array}{l}\text { C-type } \\
\text { lectin(s) }\end{array}$ & $\mathrm{MrCTL}$ & $\begin{array}{l}\text { Two CRD domains- MrCRD1 (QEP motif); } \\
\text { MrCRD2 (EPD motif) Agglutinates } \\
\text { Gram-positive and Gram-negative } \\
\text { bacteria in presence of } \mathrm{Ca}^{2+}\end{array}$ & $\begin{array}{l}\text { V. parahaemo- } \\
\text { lyticus WSSV }\end{array}$ & $\begin{array}{l}\text { Hepatopan- } \\
\text { creas }\end{array}$ & Huang et al., 2015 \\
\hline M. rosenbergii & Ficolin(s) & $\begin{array}{l}\text { MrFico1 } \\
\text { MrFico2 }\end{array}$ & $\begin{array}{l}\text { Agglutinates Gram-positive and } \mathrm{Gram} \text { - } \\
\text { negative bacteria in presence of } \mathrm{Ca}^{2+} \text {, } \\
\text { Clearance of bacteria in vivo }\end{array}$ & $\begin{array}{l}\text { V. anguillarum } \\
\text { WSSV }\end{array}$ & $\begin{array}{l}\text { Hepatopan- } \\
\text { creas }\end{array}$ & Zhang et al., 2014 \\
\hline
\end{tabular}



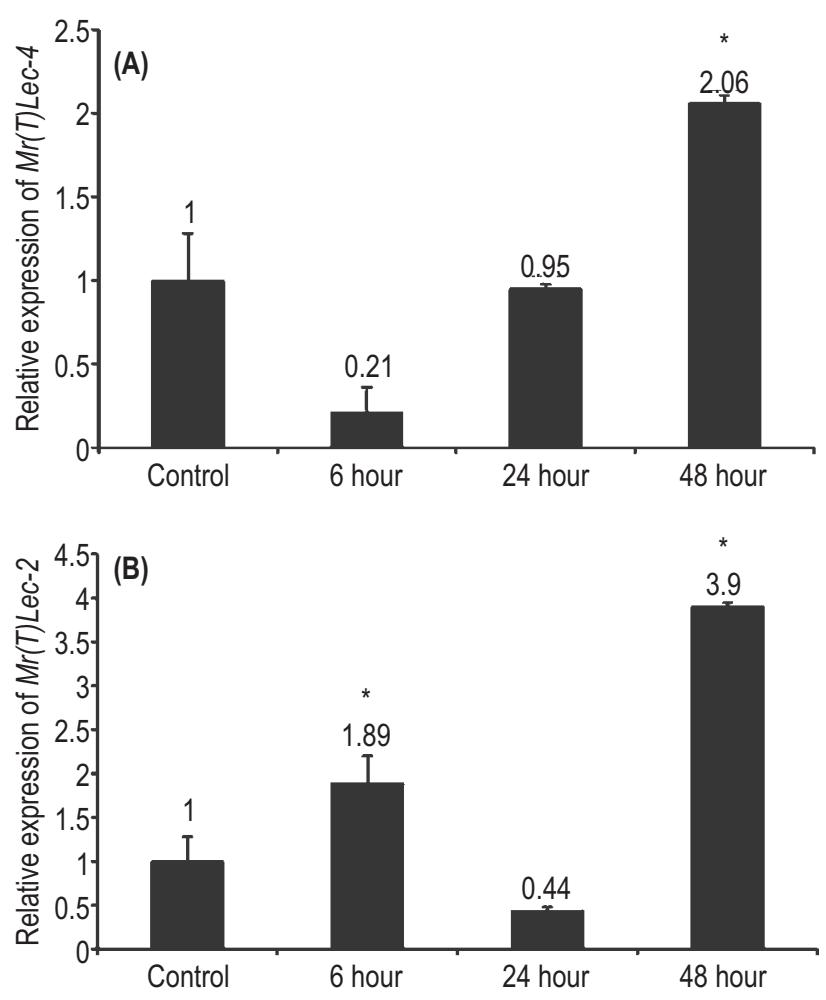

Fig. 4 : Temporal expression patterns of $M r(T) L e c-4(A)$ and $M r(T) L e c 2$ (B) in adult hepatopancreas tissue after M. rosenbergii nodavirus (MrNV) injection. MrNV was injected into M. rosenbergii adults and samples were collected at $6 \mathrm{~h}, 24 \mathrm{~h}$, and $48 \mathrm{~h}$ post-infection. Uninjected adult prawns acted as the negative control. $\beta$-actin (M. rosenbergii) was used as an internal control. Results of three biological replications are represented with standard errors. ${ }^{*} P<0.05$ (SAS, ANOVA).

This is ensured through its diverse lectin profiles (Cerenius et al., 2010; Du et al., 2013). The results are consistent to the observed transcript abundance in hepatopancreas, stomach and intestine of the crustacean, Eriocheir sinensis (Jin et al., 2013). Highest expression of lectin transcripts in hepatopancreas compared to other tissues were also recorded from the mud crab, Scylla paramamosain lectin isoforms (Jiang et al., 2012).

We were interested to understand the expression profiles of $\operatorname{Mr}(T)$ Lec4 and $\operatorname{Mr}(T)$ Lec2 in the $V$. harveyi and MrNV challenged hepatopancreas tissue of adult $M$. rosenbergii. A literature survey of last five years using PubMed with the search string 'crustacean lectins' (https://www.ncbi.nlm.nih.gov/ pubmed/?term $=$ crustacean + lectins) identified more than 40 references with immune challenge experiments. These included immunity studies in M. rosenbergii infected with Gram-positive bacteria S. aureus, Gram-negative Vibrio species like V. haemolyticus, V. parahaemolyticus, $V$. anguillarum, and the WSSV. The status survey report of lectin family transcripts expressed in various species of Macrobrachium genus with reference to immune challenge studies has been succinctly presented in Table-1. The survey suggested no studies concerning M. rosenbergii interactions with pathogenic MrNV and V. harveyi. With no potent anti-MrNV agents developed till date to prevent or control the pathogenicity of virus, understanding the requirement of lectins as an inhibitor for the development of viral pathogenicity would provide useful leads for antivirals discovery. Considering the future perspectives, this study was considered purposeful.

qRT-PCR experiments showed that $\operatorname{Mr}(T)$ Lec4 transcript level was upregulated $(P<0.05$, relative to the uninjected adult prawns) at 6 hrs ( 1.83 fold) and subsequently down-regulated at $12 \mathrm{hrs}$ and $24 \mathrm{hrs}$ upon infection by the pathogenic Gram negative bacterium, V. harveyi (Fig. 3).

No induction was noticed in the mRNA expression profile of $\operatorname{Mr}(T) L e c 2$ upon $V$. harveyi infection. In fact, the expression of transcript was significantly down-regulated during the timecourse of bacterial challenge. In another study, the expression of Marsupenaeus japonicus C-type lectin (MjHeCL) remained unaffected by V. harveyi or V. anguillarum challenge (Wang et al., 2014). Contrary to the results obtained for $\operatorname{Mr}(T) L e c 2$, the C-type lectin transcripts (C-type; dual carbohydrate recognition domain type) of $M$. rosenbergii challenged with $V$. anguillarum showed an upregulation (Ren et al., 2012). Further, a mannose-receptor was found to be induced upon $V$. anguillarum infection in red swamp crayfish, Procambrus clarkii (Man et al., 2018). In this context, it will be interesting to note the promiscuity of $\operatorname{Mr}(T) L e c 4$ and $\operatorname{Mr}(T) L e c 2$ identified in this study with homologous sequences available in the databases.

MrNV challenge also increased the expression of $\operatorname{Mr}(T) L e c 4$ in adult $M$. rosenbergii (compared with uninjected group) (Fig. 4). Post-MrNV challenge, at $6 \mathrm{hr}$, the expression of transcript was down-regulated, but upregulated at $48 \mathrm{hr}(P<0.05$, relative to uninjected control group) to 2.06 fold. MrNV challenge also significantly increased the expression of $\mathrm{Mr}(T) \operatorname{Lec} 2$ transcripts to 3.9 fold at $48 \mathrm{hr}$ time-course.

Recognition of virus by multiple species of lectins could attribute to the strong immune eliciting capability of the virus in the host. Considering the resistance of the adult $M$. rosenbergii to MrNV and its clearance after 25 days' post-infection (Sarathi et al., 2008), the present study would be significant towards understanding the lectin repertoire in conferring innate immunity. Although functional studies on the same are forthcoming, the present study will shed focus on the correlation of lectins with antiviral immune response. This will be critical to study the postlarval stages of $M$. rosenbergii known to be more susceptible to virus injury and subsequent mortality. As the exact mechanism of MrNV clearance is still unclear in most crustaceans, including prawns and shrimps, the present report on $M$. rosenbergii is crucial in the perspective of host-pathogen interactions. 


\section{Acknowledgments}

This work has been supported by Department of Biotechnology (DBT), Government of India (Gol) grant No. BT/PR12710/AAQ/3/713/2015 under the 'Aquaculture and Marine Biotechnology category. Further, A. S. Sahul Hameed acknowledges DBT, Gol for partially funding the work under R\&D project on Viral Pathogens Repositories (BT/PR12660/AAQ/ 3/710/2014).

\section{References}

Ali, H., M.M. Rahman, A. Rico, A. Jaman, S.K. Basak, M.M. Islam, N. Khan, H.J. Keus and C.V. Mohan: An assessment of health management practices and occupational health hazards in tiger shrimp (Penaeus monodon) and freshwater prawn (Macrobrachium rosenbergii) aquaculture in Bangladesh. Vet. Animal Sci., 5, 10-19 (2018).

Arockiaraj, J., M.K. Chaurasia, V. Kumaresan, R. Palanisamy, R. Harikrishnan, M. Pasupuleti and M. Kasi: Macrobrachium rosenbergii mannose binding lectin: Synthesis of MrMBL-N20 and MrMBL-C16 peptides and their antimicrobial characterization, bioinformatics and relative gene expression analysis. Fish Shellfish Immunol., 43, 364-374 (2015).

Cerenius, L., P. Jiravanichpaisal, H.P. Liu and I. Soderhall: Crustacean immunity. Adv. Exp. Med. Biol., 708, 239-259 (2010).

Denis, M., K. Thayappan, S.M. Ramasamy and A. Munusamy: Lectin in innate immunity in Crustacea. Austin Biol., 1, 1001 (2016).

Dineshkumar, M., S. Kannappan and K. Sivakumar: Effect of mangrove plant (Sesuvium portulacastrum) extract against Vibrio harveyi during shrimp larviculture. J. Environ. Biol., 38, 47-53 (2017).

Du, J., H. Zhu, P. Liu, J. Chen, Y. Xiu W. Yao, T. Wu, Q. Ren, Q. Meng, W. Gu and W. Wang: Immune responses and gene expression in hepatopancreas from Macrobrachium rosenbergii challenged by a novel pathogen Spiroplasma MR-1008. Fish Shellfish Immunol., 34, 315-323 (2013).

FAO: The State of World Fisheries and Aquaculture, Rome (2002).

FAO: Regional review on status and trends in aquaculture development in Asia-Pacific 2015 by Rohana Subasinge. FAO Fisheries and Aquaculture. Circular No. 1135/5, Rome, Italy (2015).

Feng, J., X. Huang, M. Jin, Y. Zhang, T. Li, K. Hui and Q. Ren: A C-type lectin (MrLec) with high expression in intestine is involved in innate immune response of Macrobrachium rosenbergii. Fish Shellfish Immunol., 59, 345-350 (2016).

Hsieh, C.Y., Z.B. Wu, M.C. Tung, C. Tu, S.P. Lo, T.C. Chang, C.D. Chang, S.C. Chen, Y.C. Hsieh and S.S. Tsai: In situ hybridization and RTPCR detection of Macrobrachium rosenbergii nodavirus in giant freshwater prawn, Macrobrachium rosenbergii (de Man), in Taiwan. J. Fish Dis., 29, 665-671 (2006).

Huang, X., J. L. Feng, M. Jin, Q. Ren and W. Wang: C-type lectin (MrCTL) from the giant freshwater prawn Macrobrachium rosenbergii participates in innate immunity. Fish Shellfish Immunol., 58, 136144 (2016b).

Huang, X., K. Han, T. Li, W. Wang and Q. Ren: Novel L-type lectin from freshwater prawn, Macrobrachium rosenbergii participates in antibacterial and antiviral immune responses. Fish Shellfish Immunol., 77, 304-311 (2018).

Huang, X., T. Li, M. Jin, S. Yin, W. Wang and Q. Ren: Identification of a
Macrobrachium nipponense C-type lectin with a close evolutionary relationship to vertebrate lectins. Mol. Immunol., 87, 141-151 (2017).

Huang, X., W. Li, M. Jin, F.T. Ma, Y. Huang, Y.R. Shi, L.L. Zhao, J.L. Feng, $Q$. Ren and W. Wang: Single CRD containing lectin from Macrobrachium rosenbergii (MrLec) participates in innate immunity against pathogen infections Fish Shellfish Immunol., 51, 282-290 (2016a).

Huang, X., Y. Huang, Y.R. Shi, Q. Ren and W. Wang: Function of a novel C-type lectin with two CRD domains from Macrobrachium rosenbergii in innate immunity. Dev. Comp. Immunol., 49, 121-126 (2015).

Jiang, K., D. Zhang, F. Zhang, M. Sun, L. Qi, S. Zhang, Z. Qiao and L. Ma: Isolation of a C-type lectin like-domain cDNAs from the mud crab, Scylla paramamosain Estampador, 1949, and its expression profiles in various tissues, during larval development, and under Vibrio challenge. Crustaceana, 85, 817-834 (2012).

Jin, X.K., X.N. Guo, S. Li, M.H. Wu, Y.T. Zhu, A.Q. Yu, S.J. Tan, W.W. Li, P. Zhang and $Q$. Wang: Association of a hepatopancreas-specific Ctype lectin with the antibacterial response of Eriocheir sinensis. PLoS One, 11, e76132 (2013)

Li, T., L. Wu, M. Jin, F. Ma, X. Huang and Q. Ren: Function of two ficolinlike proteins in innate immune defense of the oriental river prawn, Macrobrachium nipponense. Fish Shellfish Immunol., 68, 488-499 (2017).

Livak, K.J. and T. D. Schmittgen: Analysis of gene expression data using real-time quantitative PCR and the 2- (Delta Delta $\mathrm{C}(\mathrm{T})$ ) method. Methods, 25, 402-408 (2001).

Man, X., X.T. Pan, H.W. Zhang, Y. Wang, X.C. Li and X.W. Zhang: A mannose receptor is involved in the anti-Vibrio defense of red swamp crayfish. Fish Shellfish Immunol., 82, 258-266 (2018).

Murwantoko, M., A. Bimantara, R. Roosmanto and M. Kawaichi: Macrobrachium rosenbergii nodavirus infection in a giant freshwater prawn hatchery in Indonesia. Springer Plus, 5, 1729 (2016)

Owens, L., K. La Fauce, K. Juntunen, O. Hayakijkosol and C. Zeng: Macrobrachium rosenbergii nodavirus disease (white tail disease) in Australia. Dis. Aqua. Organis., 85, 175-180 (2009).

Ravi, M., A.N. Basha, G. Taju, R.R. Kumar and A.S.S. Hameed. Clearance of Macrobrachium rosenbergii nodavirus (MrNV) and extra small virus (XSV) and immunological changes in experimentally injected Macrobrachium rosenbergii. Fish Shellfish Immunol., 28, 428-433 (2010)

Ren, Q., M. Li, J. Du, C.Y. Zhang and W. Wang: Immune response of four dual-CRD C-type lectins to microbial challenges in giant freshwater prawn Macrobrachium rosenbergii. Fish Shellfish Immunol., 33, 155-167 (2012)

Sahul Hameed, A.S., K. Yoganandhan, J. Sri Widada and J.R. Bonami: Studies on the occurrence of Macrobrachium rosenbergil nodavirus and extra small virus-like particles associated with white-tail disease of $M$. rosenbergii in India by RT-PCR detection. Aquaculture, 238, 127-133 (2004).

Sanchez-Salgado, J.L., M.A. Pereyra, C. Agundis, O. Vivanco-Rojas, C. Sierra-Castillo, J.J. Alpuche-Osorno and E. Zenteno: Participation of lectins in crustacean immune system. Aquaculture Res., 48, 4001-4011 (2017).

Sarathi, M., A.N. Basha, M. Ravi, C. Venkatesan, B.S. Kumar and A.S.S. Hameed: Clearance of white-spot syndrome virus (WSSV) and immunological changes in experimentally WSSV-injected 
Macrobrachium rosenbergii. Fish Shellfish Immunol., 25, 222-230 (2008).

Saurabh, S. and P. K. Sahoo: Lysozyme: An important defense molecule of fish innate immune system. Aquaculture Res., 39, 223-239 (2008).

Schwantes, V.S., J.S. Diana and Y. Yi: Social, economic and production characteristics of giant river prawn, Macrobrachium rosenbergii culture in Thailand. Aquaculture, 287, 120-127 (2009).

Shailender, M., P.V. Krishna and Ch. Suresh Babu: Effects of probiotics on growth and survival of post larvae of giant freshwater prawn, Macrobrachium rosenbergii (De Man). Int. J. Bioassays, 1, 184190 (2012).

Vazquez, L., J. Alpuche, G. Maldonado, C. Agundis, A.P. Morales and E. Zenteno: Immunity mechanisms in crustaceans. Innate Immun., 15, 179-188 (2009).

Wang, X.W., J.D. Xu, X.F. Zhao, G.R. Vasta and J.X. Wang: A shrimp Ctype lectin inhibits the proliferation of hemolymph microbiota by maintaining the expression of antimicrobial peptides. J. Biol. Chem., 289, 11779-11790 (2014).

Xiu, Y., L. Hou, X. Liu, Y. Wang, W. Gu, Q. Meng and W. Wang: Isolation and characterization of two novel C-type lectins from the oriental river prawn, Macrobrachium nipponense. Fish Shellfish Immunol., 46,603-611 (2015a).

Xiu, Y., Y. Wang, J. Bi, Y. Liu, M. Ning, H. Liu, S. Li, W. Gu, W. Wang and Q. Meng: A novel C-type lectin is involved in the innate immunity of
Macrobrachium nipponense. Fish Shellfish Immunol., 50, 117-126 (2015b).

Xiu, Y., Y. Wang, Y. Jing, Y. Qi, Z. Ding, Q. Meng and W. Wang: Molecular cloning, characterization and expression analysis of two different types of lectins from the oriental river prawn, Macrobrachium nipponense. Fish and Shellfish Immunol., 45, 465-469 (2016).

Yoganandhan, K., M. Leartvibhas, S. Sriwongpuk and C. Limsuwan: White tail disease of the giant freshwater prawn Macrobrachium rosenbergii in Thailand. Dis. Aqua. Organis., 69, 255-258 (2006).

Zhang, H., J. Wang, J. Yuan, L. Li, J. Zhang, J.R. Bonami and Z. Shi: Quantitative relationship of two viruses (MrNV and XSV) in whitetail disease of Macrobrachium rosenbergii. Dis. Aqua. Organis., 71, 11-17 (2006).

Zhang, X.W., X.W. Wang, Y. Huang, K.M. Hui, Y.R. Shi, W. Wang and Q. Ren: Cloning and characterization of two different ficolins from the giant freshwater prawn, Macrobrachium rosenbergii. Dev. Comp. Immunol., 44, 359-369 (2014).

Zhang, X.W., Y. Wang, X.W. Wang, L. Wang, Y. Mu and J.X. Wang: A Ctype lectin with an immunoglobulin-like domain promotes phagocytosis of hemocytes in crayfish, Procambarus clarkii. Scientific Rep., 6, 29924 (2016).

Zhu, H., J. Du, K.M. Hui, P. Liu, J. Chen, Y. Xiu, W. Yao, T. Wu, Q. Meng, W. Gu, Q. Ren and W. Wang: Diversity of lectins in Macrobrachium rosenbergii and their expression patterns under Spiroplasma MR1008 stimulation. Fish Shellfish Immunol., 35, 300-309 (2013). 